\title{
高温超伝導 SQUID を用いたモバイル式非破壊検査装置
}

\author{
廿日出 好*
}

\section{Mobile Nondestructive Evaluation Systems using High- $T_{\mathrm{c}}$ SQUIDs}

\author{
Yoshimi HATSUKADE*
}

\begin{abstract}
Synopsis: This paper reviews the recent development of mobile nondestructive evaluation (NDE) systems using high- $T_{\mathrm{c}}$ superconducting quantum interference devices (SQUIDs) for conductive materials and structures. The contents of this paper include a noise cancellation scheme using active shielding, a novel high- $T_{\mathrm{c}}$ SQUID gradiometer with robustness in magnetic fields, mobile SQUID NDE systems and NDE of complex composite-metal structures. Using the novel high- $T_{\mathrm{c}}$ SQUID gradiometer, the superior capability of the mobile SQUID NDE system compared to conventional NDE techniques is demonstrated and discussed.
\end{abstract}

Keywords: high- $T_{\mathrm{c}}$ superconducting quantum interference device (SQUID), nondestructive evaluation (NDE), mobile system, high-pressure vessel

(Some figures in this article may appear in colour only in the electronic version)

\section{1. はじめに}

超伝導量子干涉素子 (Superconducting quantum interference device: SQUID）は，小さな超伝導リングと ジョセフソン接合から構成される, 超伝導状態における磁 束の量子化とジョセフソン効果という物理現象を組合せた 超伝導デバイスである ${ }^{1)}$ 。SQUID を磁気センサとして用 いた場合, DC から数 $\mathrm{GHz}$ までの広い周波数帯域を有し, その優れた磁場感度は周波数に依存しない。また, Flux locked loop (FLL) 回路で SQUID を駆動することで，広 いダイナミックレンジと高いスルーレート，そして線形応 答特性が得られる ${ }^{2,3)}$ 。このため, 金属系の低温超伝導 (Low- $T_{\mathrm{c}}$ ) SQUID は, 地球物理学をはじめ磁化率測定, 生体磁気計測, 電圧・電流などの物理量測定など多くの応 用に用いられてきた ${ }^{1-5)}$ 。これらの応用の中で商業的に最 も成功した例は脳磁図（Magnetoencephalogram: MEG）を 計測するマルチチャンネル型の MEG 装置であり，これに 続く実用化を目指した SQUID 応用として, 心磁図

（Magnetocardiogram：MCG）計測や非破壊評価 (Nondestructive evaluation: NDE)，免疫検查などが研究 されてきた ${ }^{6-9)}$ 。これらの研究で当初は Low- $T_{\mathrm{c}}$ SQUID が

Received March 6, 2012

* 豊橋技術科学大学 環境 - 生命工学系

干441-8580 愛知県豊橋市天伯町雲雀ケ丘 1-1

1-1 Hibarigaoka, Tenpaku-cho, Toyohashi, Aichi 441-8580, Japan

Department of Environmental \& Life Sciences, Toyohashi

University of Technology

E-mail: hatukade@ens.tut.ac.jp
用いられたが, 研究が進むにつれ, MEG ほど微弱な磁場 を計測しなくてよいため「究極の感度」よりもむしろ「実 用性」に重点が置かれることが多くなり，酸化物系の高温 超伝導 (High- $T_{\mathrm{c}}$ ) SQUID が主に用いられるようになっ た ${ }^{10-14)}$ 。

筆者は, 早くから High- $T_{\mathrm{c}}$ SQUID の開発・応用に取り組 んできた電子技術総合研究所（現産業技術総合研究所）に おいて, 1990 年後半から Low- $T_{\mathrm{c}}$ および High- $T_{\mathrm{c}}$ SQUID を用いた非破壊評価の研究に従事してきた。前述の SQUID の特徵より, SQUID 非破壊評価は, 金属表面の微 小な欠陷や金属内の深部欠陥からの低周波数磁場応答を検 出できる。このため, 金属材料・構造物を扱う産業への応 用技術が研究・開発されてきた。1990 年代初頭から, 航 空機の機体やホイールの微小・深部欠陥やエンジンタービ ンへの混入磁性異物, 高速道路の鉄筋の腐食や破断などの 検出に関する研究が行われ, 現場でルーチンワークに組み 込まれるに至った技術もあった 15-18)。一方, 電総研では 当時新たな航空機材料として用いられ始めた炭素繊維強化 複合材料に着目し，SQUID 非破壊評価の複合材料応用を 世界で最初期に取り組んだ 11,19-23)。その後も筆者は豊橋技 術科学大学にて High- $T_{\mathrm{c}}$ SQUID を用いた非破壊評価の研究 を継続しており，複合材料や金属などの導電性材料に加 え，空調用銅管やアルミ管，送電用配線，超高圧用水素夕 ンクなどの構造材・構造物の非破壊検査の研究に取り組ん できた 24-30)。これらの研究によって，High- $T_{\mathrm{c}}$ SQUID を用 いた非破壊評価技術は，表面欠陥であれば金属材料や炭素 
系複合材料のマイクロオーダーの欠陥を検出可能であり， 深部欠陥の場合 $20 \mathrm{~mm}$ 以上深部の欠陥を検出できるな ど，高いポテンシャルを有していることを示してきた。

しかしながら, 従来からよく用いられてきたバイクリス タル $\mathrm{SrTiO}_{3}$ 基板に $\mathrm{YBa}_{2} \mathrm{Cu}_{3} \mathrm{O}_{7-\mathrm{x}}$ (YBCO) 薄膜を蒸着して 作製した High- $T_{\mathrm{c}}$ SQUID を用いる場合，以下に示すような 課題があった。

（1）High- $T_{\mathrm{c}}$ SQUID を用いる非破壊評価装置は十分なス ルーレート・ダイナミックレンジを備えているが，検査対 象に印加した電流のつくる磁場や，印加した励磁磁場の漏 れ磁束が SQUID に鎖交した際， $1 \mu \mathrm{T}$ 未満の強度であって もジョセフソン接合や薄膜の結晶欠陥に磁束がトラップさ れ，これによる感度低下や磁束のジャンプによる不安定動 作が発生する ${ }^{32)}$ 。

（2）上記の理由により, 約 $50 \mu \mathrm{T}$ の地磁気が含まれる通 常環境中でのセンサの移動は困難である。このため検査方 法はセンサ固定, 対象移動という方式になり，シンプルな 形状の非磁性金属の板や管などに検査対象が制限される。 以上のような「磁場耐性が低い」という課題から， SQUID 非破壊検査技術は適用可能な対象・形状が比較的 少なく，性能をフルに発揮できない状態にあった。

そこで，我々は，High- $T_{\mathrm{c}}$ SQUID を用いた非破壊検査装 置のモバイル化というテーマに近年取り組んできた ${ }^{31-35)}$ このテーマの研究を通じて, High- $T_{\mathrm{c}}$ SQUID を冷却する小 型冷凍機の導入, 磁場ノイズキャンセル技術, 高い磁場雑 音耐性を有する SQUID センサの導入や開発などの要素技 術開発も行なってきた。このテーマ解説では, これら一連 の研究と, モバイル式 SQUID 非破壊検査装置の現状につ いて紹介する。

\section{2. アクティブシールドを用いたモバイル式 SQUID 非破壊評価装置}

\section{1 非破壊評価装置}

Low- $T_{\mathrm{c}}$ SQUID が用いられた初期の非破壊評価装置で は, SQUID の高感度を保持するため磁気シールドルーム 内に装置が構築されていた。その後, 装置の扱い易さ等の 実用性が考慮され, 環境磁気ノイズをキャンセルでき, 磁 気シールドがない通常の環境で動作可能な平面一次微分型 High- $T_{\mathrm{c}}$ SQUID グラジオメータを用いた装置が開発され た 19,24)。これらの装置では, SQUID は固定され, xy ス テージやモータにより検査対象が移動され, 検査が行われ る方式であった。筆者らはこれら装置の実用化のため，ま ず，低振動・低磁気ノイズ特性を有する同軸型パルス管冷 凍機を開発・導入した ${ }^{36)}$ 。クライオスタット一体型パル ス管冷凍機底部断面の概略図を Fig. 1 に示す。同軸型のた めパルス管冷凍機の冷却端の振動は数 $10 \mu \mathrm{m}$ 程度である が，振動によるノイズ増加をさらに抑制するため, SQUID を冷却するステージを冷凍機冷却端から分離し,
両者を銅の細線を用いて熱的に接続した。ステージの振動 は, 冷凍機の駆動周波数 $2.4 \mathrm{~Hz}$ において約 $0.5 \mu \mathrm{m}, 3$ 倍 高調波の $7.2 \mathrm{~Hz}$ において約 $1.3 \mu \mathrm{m}$ であった ${ }^{31)}$ 。SQUID 冷 却ステージには抵抗性ヒータと熱電対が設置され, 温度調 整コントローラで PID 制御により $77 \mathrm{~K}$ 以下に $00.04 \mathrm{~K}$ 程 度の誤差で温調されている。

次に，この冷凍機で冷却した High- $T_{\mathrm{c}}$ SQUID グラジオ メータを, 磁気シールドの無い通常環境中で移動させるた め, SQUID とは別の参照センサを用いたアクティブシー ルド技術を開発した。ここでは, 地磁気中でも安定して動 作するが，High- $T_{\mathrm{c}}$ SQUID より 2，3 桁ノイズレベルの高 いフラックスゲート磁気センサを用いて, SQUID 周辺に 常時低磁場空間を発生させるアクティブ磁気シールド技術 を開発した。この技術を，冷凍機で冷却したバイクリスタ ル接合型 High- $T_{\mathrm{c}}$ SQUID グラジオメータ（Fig. 2 参照）に 適用し, 通常環境中での SQUID グラジオメータの移動・

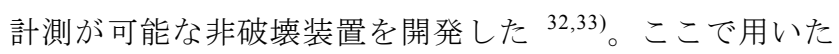
SQUID グラジオメータは, Fig. 2 の挿入図に示すように, SQUID リングのバイクリスタル粒界線上に 2 個のバイク リスタル型ジョセフソン接合（Josephson junction: JJ）を有 する。一方，ピックアップコイルにも粒界が存在してお り, 粒界における臨界電流 $I_{\mathrm{c}}$ は通常の薄膜部より 3 桁ほ ど小さい。このグラジオメータに数 10〜100 nT の磁場を 印加した場合, もしくは地磁気中で移動させた場合, ピッ クアップコイルに流れる遮蔽電流が粒界の $I_{\mathrm{c}}$ を超え, 磁 束が粒界に侵入して不安定動作を引き起こす。そこで, こ こでは通常環境中で数 $10 \mu \mathrm{T}$ の磁気ノイズが存在しても安 定に動作する約 $10 \mathrm{pT} / \mathrm{Hz}^{1 / 2}$ の感度を有するフラックス ゲートを環境磁気計測に用いた。そして, Fig. 3 に示すよ うに, フラックスゲートの出力電圧をアンプで増幅, フィ

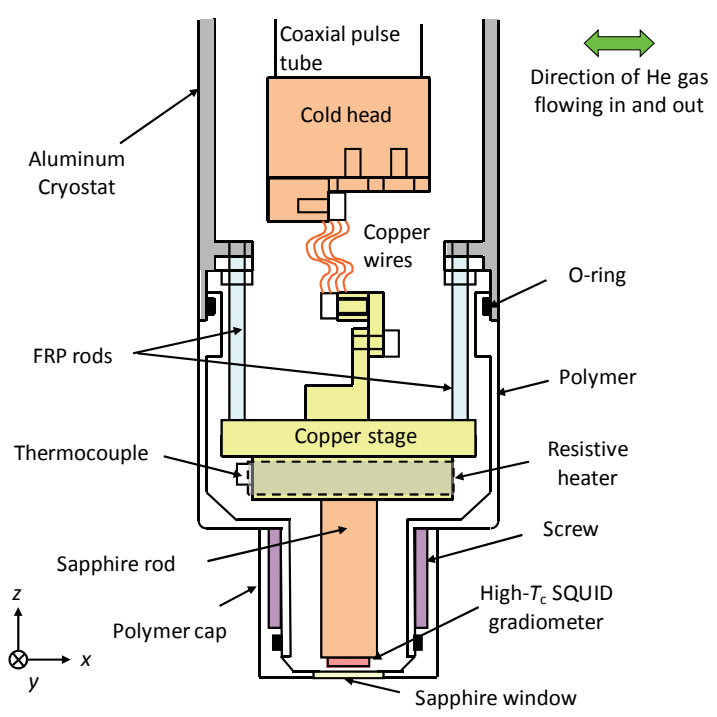

Fig. 1 Schematic illustration of the cross-section of the bottom part of the coaxial pulse-tube cryocooler. 


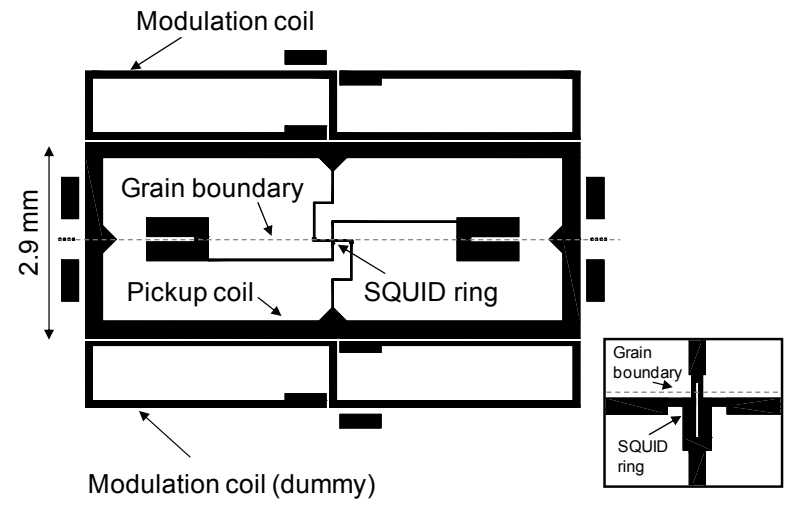

Fig. 2 Pattern of the planar high- $T_{\mathrm{c}}$ SQUID gradiometer.

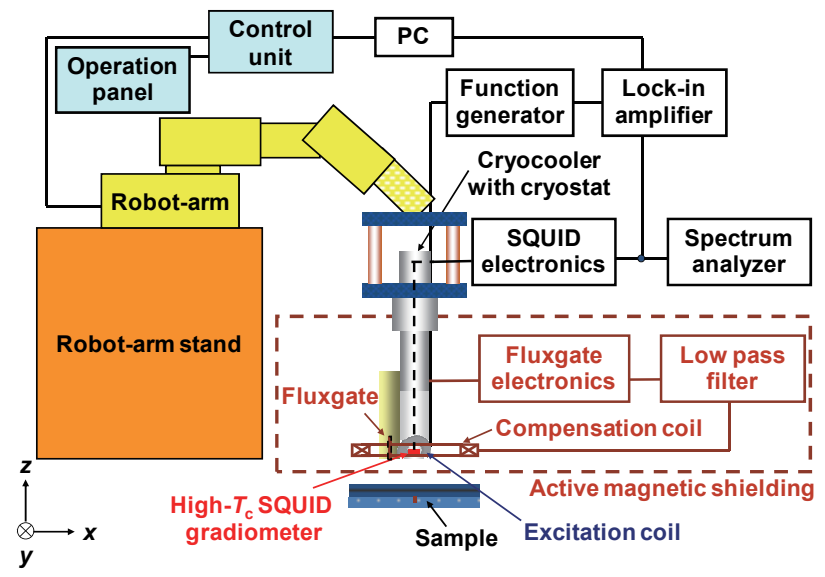

Fig. 3 Mobile high- $T_{\mathrm{c}}$ SQUID NDE system utilizing the fluxgate magnetic sensor for active magnetic shielding.

ルタにより帯域を低周波数（例えば $100 \mathrm{~Hz}$ 以下）に制限 し，補償コイルにフィードバックして補償磁場を発生さ せ, 地磁気や電源ノイズ $(50 \sim 60 \mathrm{~Hz})$ を含めた低周波数 帯域に関して，環境磁気ノイズをアクティブにキャンセル するフィードバック回路を開発した。これによりフラック スゲート近傍に常時低磁場空間が形成され，通常環境中に て SQUID グラジオメータをロボットアームで移動させて も安定動作が可能となった。Fig. 4 にロボットを用いて $100 \mathrm{~mm} / \mathrm{s}$ で SQUID グラジオメータを移動させたときの磁 束ノイズを示す。SQUID のノイズは移動前から幾分増加 したが十分に低いノイズレベルであった。ノイズの増加 は, ロボット由来のノイズか, SQUID に生じた磁束卜 ラップ由来の感度低下によるものと考えられる。

\section{2 複合材・金属材積層サンプルへの適用}

Fig. 3 に示すようなモバイル式 SQUID 非破壊評価装置 の応用の一つとして, 高い安全性が要求される水素燃料夕

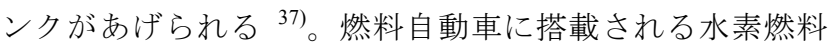
タンクは， $35 \mathrm{MPa}$ の高圧水素を貯蔵し，燃料補充のたび に大きな負荷が繰り返しかかるため，肉厚のアルミ合金の

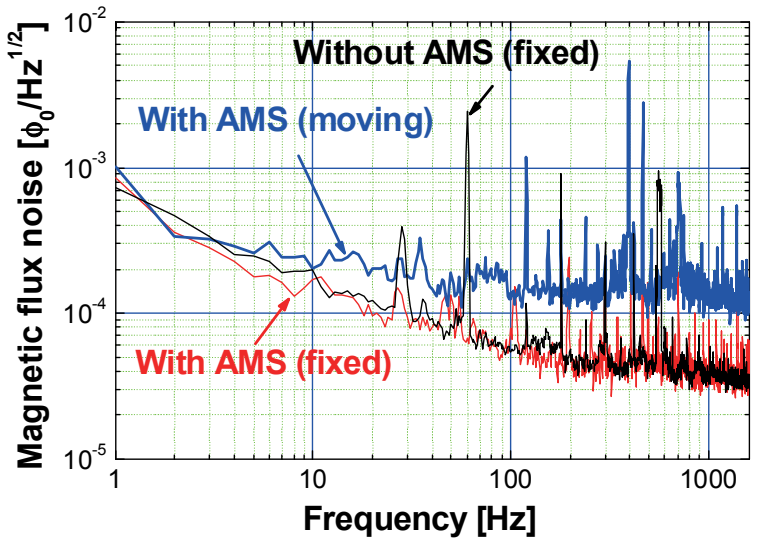

Fig. 4 Flux noise profiles of the mobile SQUID NDE system with the active magnetic shielding (AMS) technique.

ライナー (内張) を CFRP 外層で強化した構造となってい る。このようなタンクの実用化・普及のためには, 使用中 のタンクに万一微小な亀裂がライナー内部に発生した際に 早期検出できる検查技術が必須である。しかし，ライナー は数〜10 $\mathrm{mm}$ と肉厚で, $\mathrm{CFRP}$ 外層で補強されている構造 のため, 渦流探傷法や超音波探傷法など従来技術によるラ イナ一内部の欠陥検査は困難である。そこで, Fig. 3 に示 寸装置を用いて, 水素燃料タンクの CFRP ・ $\mathrm{Al}$ 合金積層構 造を模擬した板材サンプルの内部欠陥の検出を行った。

$\mathrm{CFRP} \cdot \mathrm{A} 1$ 合金積層サンプルはそれぞれ $3 \mathrm{~mm}$ と $10 \mathrm{~mm}$ の厚さを持つ $\mathrm{CFRP} と \mathrm{Al}$ 合金平板を重祇たもので，アルミ 合金裏面に幅 $2 \mathrm{~mm}$, 長さ $10 \mathrm{~mm}$, 深さ $5 \mathrm{~mm}$ の切り欠き久 陥を作製した。ここでは，鉄心入電磁コイルを用いた渦電 流法 ${ }^{21}{ }^{23}$ )を適用し, 約 $1 \mu \mathrm{T}$ で $70 \mathrm{~Hz}$ (一般的な $\mathrm{Al}$ への侵 入深さは約 $10 \mathrm{~mm}$ ) の励磁磁場をサンプルに印加しなが ら, ロボットによりサンプル表面から $3 \mathrm{~mm}$ 離れた $x y$ 平面 内で SQUID グラジオメータを移動させて二次元走查を 行った。この際, 上記アクティブシールドにおけるローパ

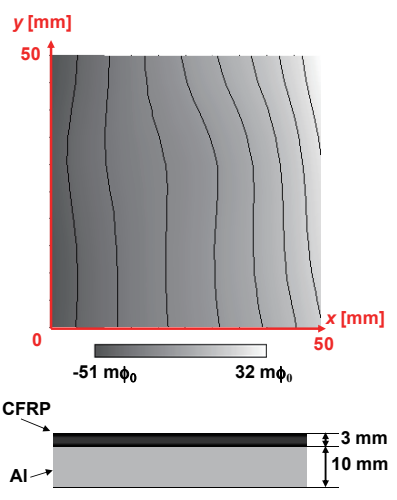

(a)

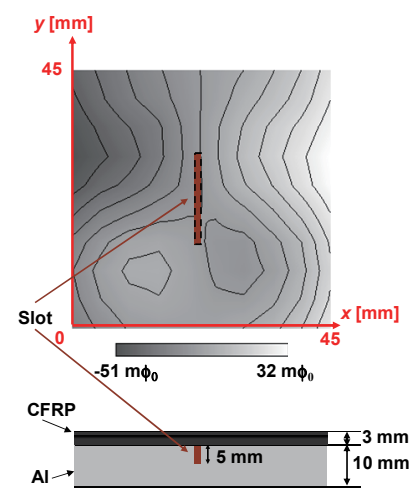

(b)
Fig. 5 Results of two-dimensional scanning using the mobile SQUID NDE system on a CFRP-covered Al plate: (a) without a slot, (b) with a slot on the near surface of the Al board. 
スフィルタのカットオフ周波数は $50 \mathrm{~Hz}$ とした。Fig. 5 に 測定結果を示す。比較のため, $\mathrm{Al}$ 合金に欠陥を持たない同 積層構造のサンプルの測定結果を同図(a)に示す。Al 合金の 表面に亀裂がある場合の検査結果を同図 (b)に示す。同図 (a)にも見られる緩やかな磁場勾配分布中に，四重極分布を もつ局所的欠陥応答が検出された。また，亀裂がアルミ合 金の裏面にある場合も同様の欠陥応答を検出することがで きた。以上の結果から, High- $T_{\mathrm{c}}$ SQUID グラジオメータを 用いたロボット式検査装置により, 肉厚・積層構造材の内 部欠陥による磁気応答を検出できる可能性が示された。

\section{3 次元構造物のためのモバイル式 SQUID 非破壊 評価装置}

\section{1 高磁場耐性 SQUID}

近年, 超電導工学研究所の田辺らのグループらによっ て，高温超伝導薄膜積層技術を用いたランプエッジ型ジョ セフソン接合をもつ High- $T_{\mathrm{c}}$ SQUID グラジオメータが開発 された ${ }^{38)}$ ここのグラジオメータは，Fig. 2 とほぼ同形状の 平面一次微分型直接結合型グラジオメータであるが,

SQUID リング中に高温超伝導薄膜積層技術を用いたランプ エッジ型ジョセフソン接合が用いられている（Fig. 6)。本 グラジオメータは, $77 \mathrm{~K}$ 冷却時に約 $50 \mu \mathrm{V}$ という高い磁束 電圧変調深さ $V_{\mathrm{pp}}$ を有し, 磁気シールドルーム中で計測し た磁束ノイズは約 $6 \mu \phi_{0} / \mathrm{Hz}^{1 / 2}$ であった。本素子はバイクリ スタル型ジョセフソン接合をもつグラジオメータと異な り，差分型ピックアップコイルに $I_{\mathrm{c}}$ を制限するような粒界 が存在しない。また, 計測磁場成分に対して粒界が平行で 磁束が侵入しやすいバイクリスタル型と異なり，ランプ エッジ型の場合，接合粒界は基板面に対して $30^{\circ}$ の角度を 有し，かつ上下の高温超伝導電極にはさまれた構造となっ ている。このようなランプエッジ型接合をもつグラジオ エータの構造から, 本素子は従来型と比較して優れた磁場 耐性を有すると考えられた。

そこで，上記新型グラジオメータに AC および DC 磁場 を印加した際の磁場耐性を調べた ${ }^{35)}$ 。磁気シールドルーム の中で, 直径 $50 \mathrm{~mm}$ の円形コイルの中心に上記 SQUID グ ラジオメータを設置して，素子基板と垂直な方向に $100 \mathrm{~Hz}$ の交流磁場を印加して, 磁束トラップが発生する磁場強度 を調べた。この実験で, 磁場強度を増加していったとき, FLL 回路のロックが外れる現象が生じた。この場合，ロッ クが外れたまま印加磁場を目標值まで上げ，その後磁場を 除去し, FLL 回路を再ロックしてノイズを計測した。この 結果, $100 \mathrm{~Hz}$ の交流磁場の場合, 振幅 $1.4 \mathrm{mT}$ の磁場印加 後までノイズの増加や磁束トラップが生じなかった（Fig. 7)。この結果と比較して，バイクリスタル型接合を有する ほぼ同形状の従来型 High- $T_{\mathrm{c}}$ SQUID グラジオメータの場 合，磁場振幅が約 $30 \mathrm{nT}$ に達したときに磁束トラップによ るノイズ増加が確認された。後者の場合, ピックアップコ
イルに粒界が存在するため, 印加された磁場に応じて発生 する遮蔽電流がピックアップコイルの粒界部の臨界電流值 を超えたときに常伝導転移が発生し, この部分に量子磁束 がトラップされ，ノイズが増加したものと考えられる。

一方，SQUID 基板に対して垂直な方向に DC 磁場を印加 してその強度を増加させながら, SQUID グラジオメータの 二個のジョセフソン接合の合計の臨界電流值 $I_{\mathrm{c}}$ の值を計測 した。この結果を Fig. 8 に示す。比較のため, バイクリス タル型接合を有する, ピックアップコイルを持たない High- $T_{\mathrm{c}}$ SQUID リングの臨界電流值も計測した。図に示寸 ように，バイクリスタル型の SQUID リング場合, DC 磁場 の増加に従い, 寸みやかに臨界電流值は減少し, $120 \mu \mathrm{T}$ 付 近で最小となり, $240 \mu \mathrm{T}$ 付近で最大值を示し, その後 350 $\mu \mathrm{T}$ 以降はほぼゼロとなった。一方, ランプエッジ型 SQUID グラジオメータの場合, 約 $160 \mu \mathrm{T}$ までは $I_{\mathrm{c}}$ は緩や かに減少し, その後 $700 \mu \mathrm{T}$ 付近で最小值が現れた。このよ うにランプエッジ型ジョセフソン接合をもつ新型の SQUID グラジオメータは，AC および DC 磁場に対する高い耐性 を有しており, 磁気シールドの無い通常環境中で地磁気を 切るように三次元的に移動させても, 低速度ならロックが 外れることなく安定に動作し続けることがわかった ${ }^{34)}$

上記グラジオメータの磁場耐性が接合の積層構造による ものと考えられたため, 我々は，ピックアップコイルがバ イクリスタル粒界に交差しないマルチループ構成の High- $T_{\mathrm{c}}$

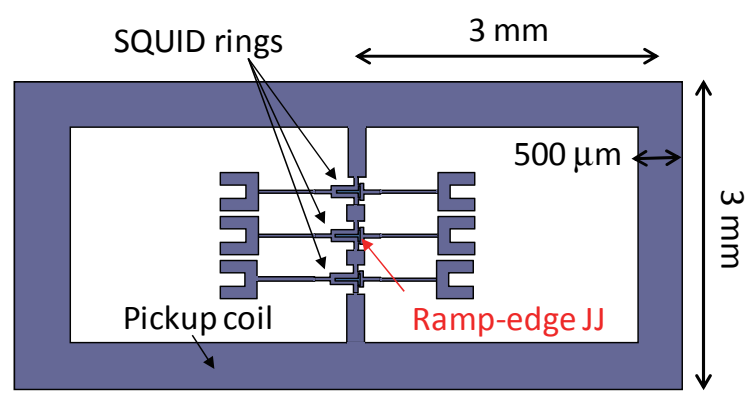

(a)

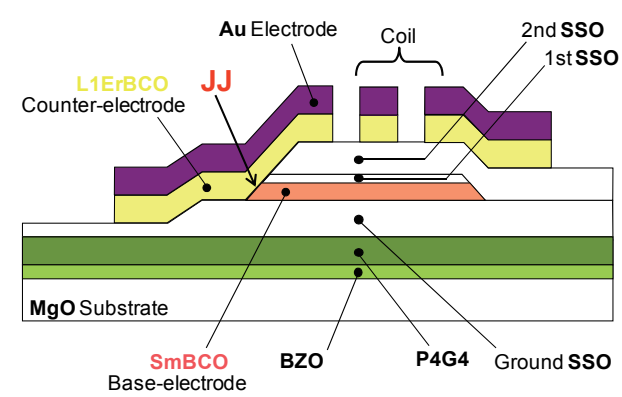

(b)

Fig. 6 Novel high- $T_{\mathrm{c}}$ SQUID gradiometer with ramp-edge Josephson junctions: (a) schematic pattern of the gradiometer, (b) schematic drawing of the cross-section of the multi-layer ramp-edge Josephson junction. 
SQUID マグネトメータを設計（Fig. 9)，バイクリスタル STO 基板上に作製した。そして, 別の通常の STO 基板に YBCO 薄膜を蒸着し, 上記マグネトメータのマルチループ の隙間および素子中心の SQUID リングを覆うような十字 型 YBCO 薄膜を作製し，同図右下の挿入困に示すように， フリップチップ構造でマグネトメータ上に積層した。この マグネトメータの臨界電流值 $I_{\mathrm{c}}$ の值を, 上記同様 DC 磁場 を印加しながら計測した。この結果，Fig. 10 に示すよう に, YBCO 薄膜を積層したマグネトメータの場合, 約 160 $\mu \mathrm{T}$ まで $I_{\mathrm{c}}$ はほとんど減少せず， $160 \mu \mathrm{T}$ 以上では減少して

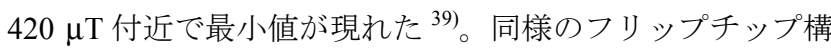
造により, AC 磁場を印加した際の High- $T_{\mathrm{c}}$ SQUID マグネ トメータの磁場耐性が増加することが報告されており，積 層構造の磁場に対する優位性が明らかになっている ${ }^{40)}$ 。

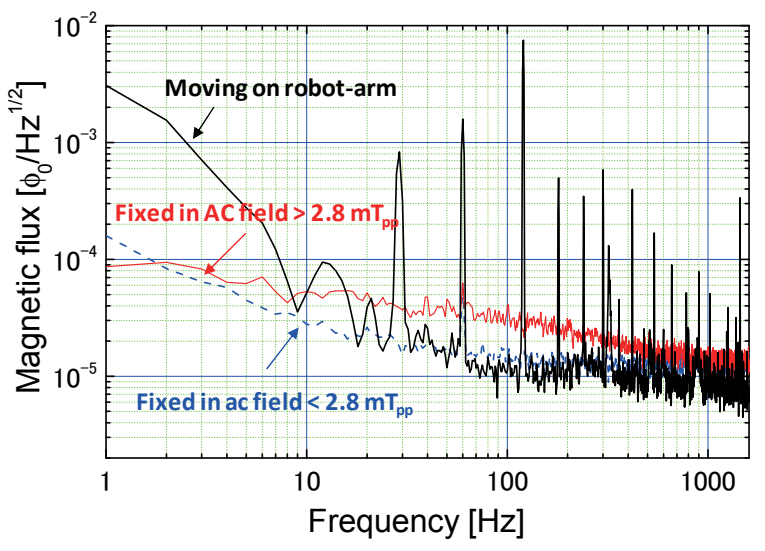

Fig. 7 Flux noise profiles of the high- $T_{\mathrm{c}}$ SQUID gradiometer with ramp-edge Josephson junctions when fixed in a magnetically shielded room or moved in a normal environment.

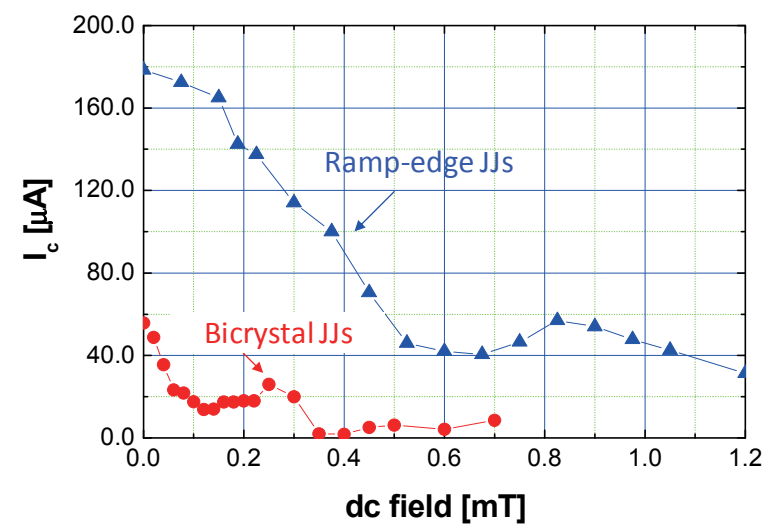

Fig. 8 Critical current $I_{\mathrm{c}}$ of the high- $T_{\mathrm{c}}$ SQUID gradiometer with ramp-edge Josephson junctions and high- $T_{\mathrm{c}}$ SQUID ring with bicrystal Josephson junctions versus applied DC field.

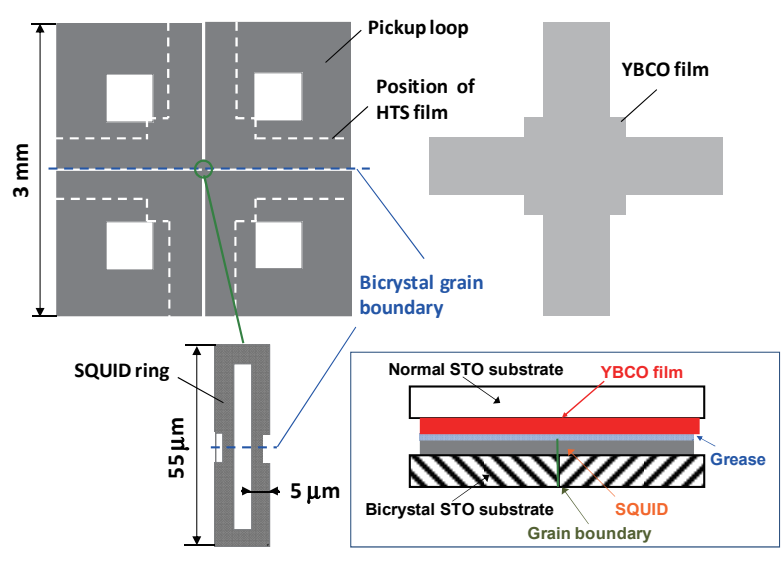

Fig. 9 High- $T_{\mathrm{c}}$ SQUID magnetometer with a multi-pickuploop design. The bicrystal grain boundary does not cross the multi-pickup-loop. Another cross-shaped YBCO film was overlapped on the SQUID magnetometer with a flip-chip configuration.

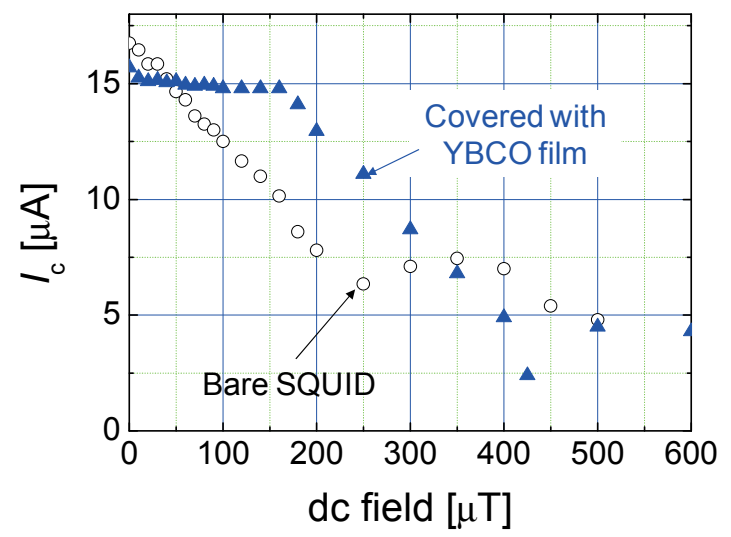

Fig. 10 Critical current $I_{\mathrm{c}}$ of the high- $T_{\mathrm{c}}$ SQUID magnetometer with multi-pickup-loop and bicrystal Josephson junctions covered with and without YBCO film in a flip-chip configuration versus applied DC field.

\section{2 高磁場耐性 SQUID グラジオメータを用いた 3 次元 モバイル式 SQUID 非破壊評価装置}

高磁場耐性を有する Fig. 6 に示す High- $T_{\mathrm{c}}$ SQUID グラジ オメータを，ロボットアーム搭載用に開発した重量約 500 $\mathrm{g}$ の軽量・小型クライオスタット（Fig. 11）にマウントし て約 $78.6 \mathrm{~K}$ に冷却した。この小型クライオスタットをロ ボットアームに搭載し, Fig. 12 に示すような検査装置を 構築した。SQUID と室温間最小距離は約 $1.5 \mathrm{~mm}$ である。

Fig. 7 に, このグラジオメータを磁気シールドの無い通常 環境で $10 \mathrm{~mm} / \mathrm{s}$ の速度で移動させた場合の磁束ノイズを示 す。図に示すように，移動中のノイズ特性は，鎖交する地 磁気の影響により $10 \mathrm{~Hz}$ 以下の低周波数領域でノイズが少 し増加しているが，その他は通常環境で見られる $60 \mathrm{~Hz}$ と その高調波成分が見られるだけで, 移動後, 磁束トラッ 


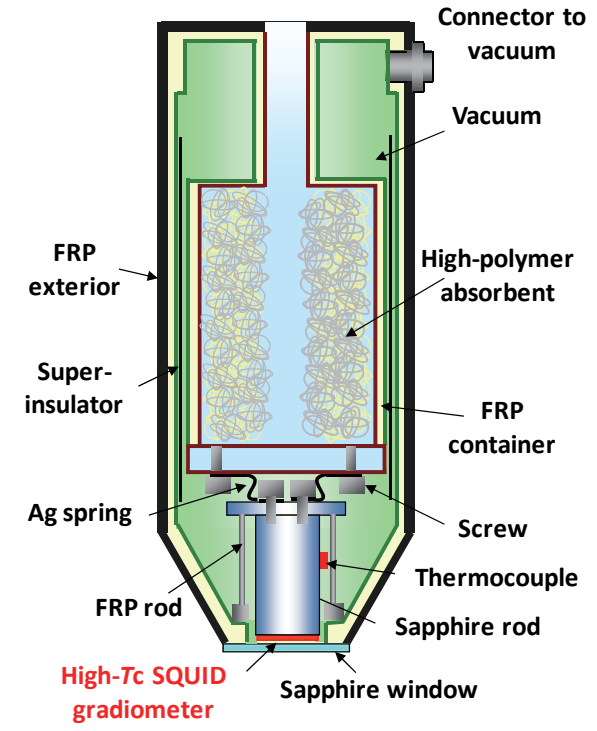

Fig. 11 Small cryostat for the 3D-mobile SQUID NDE system.

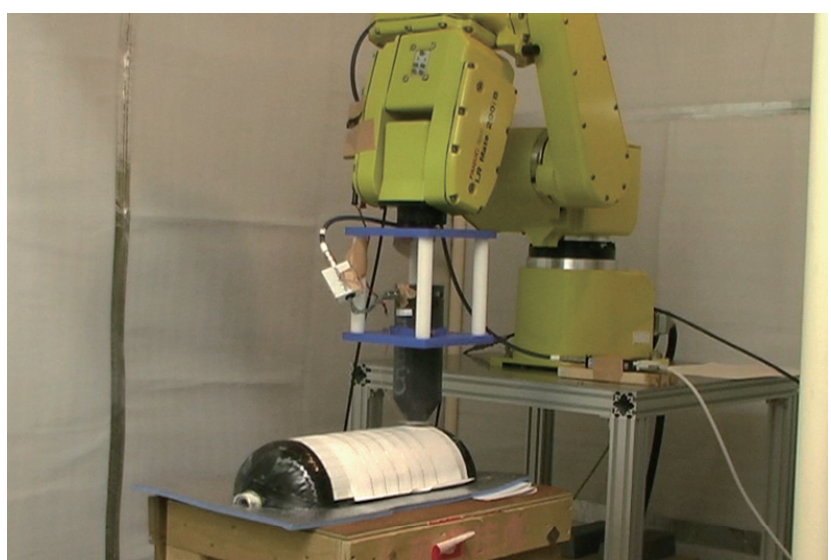

Fig. 12 3D-mobile SQUID NDE system utilizing the high- $T_{\mathrm{c}}$ SQUID gradiometer with ramp-edge Josephson junctions for the high-pressure vessel.

プ・ジャンプによる $1 / f$ ノイズの増加や感度低下などは見 られなかった。この装置は軽量で小型のクライオスタット を用いるため, 数 $10 \mathrm{~cm}$ の範囲で三次元走査が可能である。 また，新型グラジオメータの磁場耐性のため, 従来よりも 大きな励磁磁場の印加が可能となった。

\section{3 水素タンクの非破壊評価}

上記ロボット式 SQUID 非破壊評価装置を用いて，Fig. 12 に示す円筒ドーム形状の水素然料タンクの周辺の曲面内 を, リフトオフを一定に保ったままグラジオメータを移動 させ, その曲面内の磁場勾配分布を計測し, タンク内部欠 陥を検出する自動計測プログラムを開発した。上記装置と プログラムを用いて，タンクのアルミライナーに存在する 貫通亀裂の検出を行った。このタンクは圧力試験用に試供 された小型の水素燃料用タンクで, 円筒部の直径 $168 \mathrm{~mm}$, 軸長さ $420 \mathrm{~mm}$, 内部アルミライナーと外部 CFRP 層の厚 さ各 $3 \mathrm{~mm}$ の円筒ドーム形状タンクである。このタンクに
油圧による負荷を繰返し与えることにより，アルミライ ナー内表面に長さ約 $10 \mathrm{~mm}$ の周方向亀裂が発生した。この タンクに対して, Fig. 13(a)に示すように, SQUID グラジオ メータのベースラインをタンクの軸方向（ $y$ 方向）に平行, 計測成分をタンク半径方向と垂直な磁場の勾配 $\mathrm{d} B_{\mathrm{r}} / \mathrm{d} y \quad\left(B_{\mathrm{r}}\right.$ は半径方向成分の磁場）とし, リフトオフ $5 \mathrm{~mm}$ でタンク 周辺の曲面内で SQUID を三次元走査させた。この際, ク ライオスタットの底部に設置したダブル D コイルを用いて 低周波数励磁を行いながら, アルミライナー内部に発生す る渦電流による亀裂応答磁場の測定を行った。Fig. 13(b)に, $7.5 \mu \mathrm{T}, 1 \mathrm{kHz}$ (Alへの侵入深さは約 $2.6 \mathrm{~mm}$ ) の励磁磁場 を用いた場合の, 亀裂周辺曲面内での磁場勾配分布の測定 結果を示す。ここでは, 同図(a)に示す走査曲面の回転角度 を $w$ として, $y w$ 曲面の磁場勾配 $\mathrm{d} B_{\mathrm{r}} / \mathrm{d} y$ に比例した SQUID 出力電圧を, $x y$ 平面に投影した二次元分布を同図(b)に示し た。亀裂中心を重心とした四重極分布の亀裂応答信号を,

Fig. 5 の場合よりずっと大きな $\mathrm{S} / \mathrm{N}$ で検出することができ た。また, 励磁周波数を変化させて測定を行った結果,

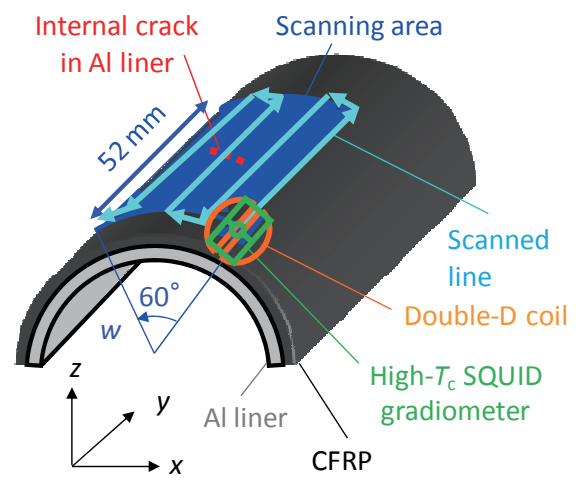

(a)

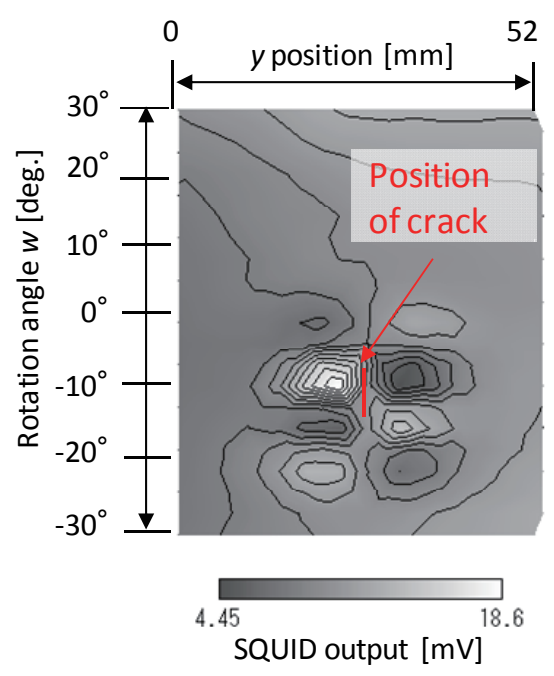

(b)

Fig. 13 (a) Inspection scheme for internal cracks in the highpressure vessel using the 3D-mobile SQUID NDE system, (b) inspection result. 


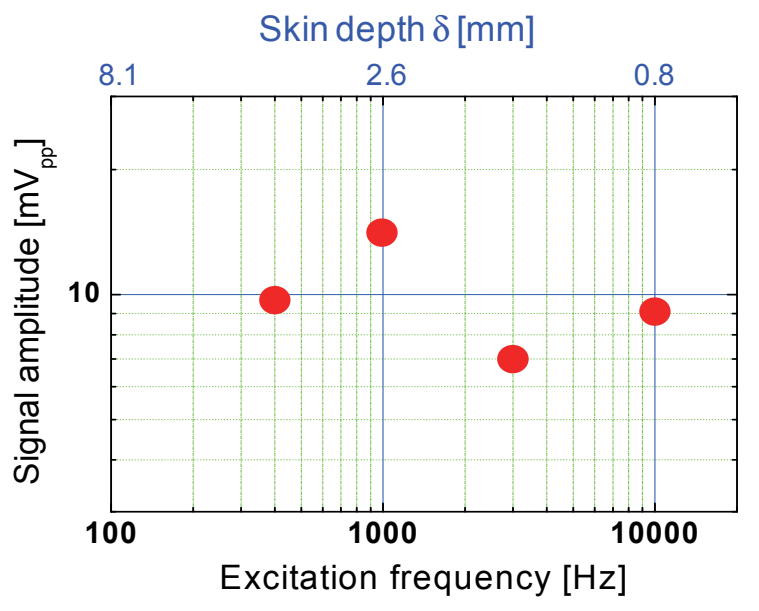

Fig. 14 Relationship between the excitation frequency and the signal amplitude from an internal crack in the high-pressure vessel. Skin depth corresponding to the frequency is also shown.

侵入深さとアルミライナーの厚さがほぼ一致する $1 \mathrm{kHz}$ で 最も大きな信号強度が得られた（Fig. 14）。

以上で示したように，これまでは困難であったロボット による High- $T_{\mathrm{c}}$ SQUID の二次元および三次元走査が可能と なっており, 水素然料タンクのような複雑な形状の先進構 造物を非接触で深部まで検査可能なモバイル式ロボット SQUID 非破壊検査装置が実現されている。また，ここで示 した高い磁場耐性をもつグラジオメータに対して，2.1 で 示したアクティブ磁気シールド技術を応用して，グラジオ メータ出力を補償コイルにフィードバックすることで，他 の参照センサを用いることなく, 残留磁化をもつステンレ スなどの磁性体にも数 $\mathrm{mm}$ 以内まで接近して検査すること が可能なことがこれまでに示されている ${ }^{34)}$

\section{4. まとめと今後の展望}

本解説では，モバイル式 SQUID 非破壊評価装置開発の 近年における進捗について紹介した。ノイズキャンセル技 術や磁場耐性の高い SQUID 素子の開発により，SQUID 非 破壊評価技術によって検查可能な対象は複雑な構造物から 磁性材料に至るまで大幅に拡張されている。さらに高い磁 場而性を有する High- $T_{\mathrm{c}}$ SQUID マグネトメータも開発され つつあり，深部欠陥の検出に対してより有効な装置の開発 が行われている。近い将来における工業用 SQUID 非破壊 検査装置の実用化が強く期待されるところである。

本解説は，低温工学協会から奨励賞を頂いた 2008 年前 後からそれ以降におけるモバイル式 SQUID 非破壊検査装 置の研究についてまとめたものです。このような解説の執 筆の機会を与えていただいた低温工学・超電導学会, そし て学会誌出版委員長であり, 恩師でもある早稲田大学の石 山敦士教授に心より感謝致します。また, 電子技術総合研
究所・産業技術総合研究所での共同研究者であった葛西直 子氏, 元岩谷瓦斯株式会社の丸野善生氏, 国際超電導産業 技術研究センター・超電導工学研究所の田辺圭一氏, 安達 成司氏，(株)クラオウェアの藤岡耕治氏，サムテック株， 豊橋技術科学大学の田中三郎教授, 田中・廿日出研究室の 研究室 $\mathrm{OB} \cdot \mathrm{OG} ・$ 現役学生に感謝致します。

\section{参 考 文 献}

1) A. Barone and G. Paterno: "Physics and Applications of the Josephson Effect”, John Wiley \& Sons, Inc., New York (1982)

2) A. Barone (Ed.): "Principle and Application of Superconducting Quantum Interference Devices", World Scientific, Singapore, (1992)

3) H. Weinstock (Ed.): "SQUID Sensors: Fundamentals, Fabrication and Applications", Kluwer Academic Publishers (1996)

4) J. Clarke and A.I. Braginski (Eds.): "SQUID handbook I", WILEY-VCH GmbH \& Co. KGaA, Weinheim (2004)

5) J. Clarke and A.I. Braginski (Eds.): "SQUID handbook II", WILEY-VCH GmbH \& Co. KGaA, Weinheim (2006)

6) D. Cohen: "Magnetoencephalography: evidence of magnetic fields produced by alpha-rhythm current", Science 161 (1968) 784-786

7) D. Cohen, E.A. Edelsack and J.E. Zimmerman: "Magnetocardiograms taken inside a shielded room with a superconducting point-contact magnetometer", Appl. Phys. Lett. 16 (1970) 278-280

8) G.B. Donaldson: "SQUIDs for everything else" in H. Weinstock and M. Niesenoff (Eds.): "Superconducting Electronics", Springer, Berlin (1989) 175-207

9) W. Weitschies, R. Kötitz, T. Bunte and L. Trahms: "Determination of relaxing or remnant nanoparticle magnetization provides a novel binding specific technique for the evaluation of immunoassays", Pharm. Pharmacol. Lett. 7 (1997) 5-8

10) D. Suzuki, A. Tsukamoto, K. Yokosawa, A. Kandori, et al.: "A mobile and space-saving high-temperature superconducting multichannel magnetocardiograph in a vertically magnetically shielded cylinder", Jpn. J. Appl. Phys. 43 (2004) 117-120

11) N. Kasai, D. Suzuki, H. Takashima, M. Koyanagi and Y. Hatsukade: "HTS-dcSQUID gradiometer for nondestructive evaluation", IEEE Trans. Appl. Supercond. 9 (1999) 4393-4396

12) H. Itozaki, T. Nagaishi, H. Toyoda and H. Kugai: "Detection of fine iron particles in high speed scrolled wire by high $T_{\mathrm{c}}$ SQUID", IEICE Trans. Electron. E80-C (1997) 1247-1251

13) S. Tanaka, M. Natsume, M. Ucnida, N. Hotta, T. Matsukade, Z. A spanut and Y. Hatsukade: "Measurement of a metallic contaminant in food by high- $T_{\mathrm{c}}$ SQUID”, Supercond. Sci. Technol. 17 (2004) 620-623

14) K. Enpuku and T. Minotani: "Biological immunoassay with high $T_{\mathrm{c}}$ superconducting quantum interference device (SQUID) magnetometer", IEICE Trans. Electron. E84C (2001) 43-48

15) R. Hohmann, M. Maus, D. Lomparski, M. Greuneklee, Y. Zhang, H. -J. Krause, H. Bousack and A. I. Braginski: "Aircraft wheel testing with machine-cooled HTS SQUID gradiometer system", IEEE Trans. Appl. Supercond. 9 (1999) 3801-3804

16) K. Allweins, G. Gierelt, H.-J. Krause and M.v. Kreutzbruck, "Defect detection in thick aircraft samples based on HTS SQUIDmagnetometry and pattern recognition", IEEE Trans. Appl. Supercond. 13 (2003) 250-253 
17) Y. Tavrin, M. Siegel and J. Hinken: "Standard method for detection of megnetic detects in aircraft engine discs using HTS SQUID gradiometer“, IEEE Trans. Appl. Supercond. 9 (1999) 3809-3812

18) H.-J. Krause, W. Wolf, W. Glaas, E. Zimmermann, M.I. Faley, G. Sawade, R. Mattheus, G. Neudert, U. Gampe and J. Krieger: "SQUID array for magnetic inspection of prestressed concrete bridges", Physica C 368 (2002) 91-95

19) N. Kasai, D. Suzuki, Y. Hatsukade and M. Koyanagi,: "Nondestructive detection of flaw in carbon-fiber-reinforced plastics using high- $T_{\mathrm{c}}$ superconducting quantum interference device”, Jpn. J. Appl. Phys. 39 (2000) 1399-1404

20) Y. Hatsukade, N. Kasai and A. Ishiyama: "Nondestructive detection of delamination in carbon-fiber-reinforced plastics using high- $T_{\mathrm{c}}$ superconducting quantum interference device”, Jpn. J. Appl. Phys. L606 (2001) 40-42

21) Y. Hatsukade, N. Kasai, H. Takashima and A. Ishiyama: "Noncontact SQUID-NDT method using ferrite core for carbon-fiber composites", Supercond. Sci. Technol. 15 (2002) 1728-1732

22) Y. Hatsukade, M. S. Aly-Hassan, N. Kasai, H. Takashima, H. Hatta and A. Ishiyama: "SQUID-NDE method on damaged area and damage amount of defects in composite materials", IEEE Trans. Appl. Supercond. 13 (2003) 207-210

23) Y. Hatsukade, T. Inaba, N. Kasai, Y. Maruno, A. Ishiyama and S. Tanaka: "Detection of deep-lying defects in carbon fiber composites using SQUID-NDE system cooled by a cryocooler", Physica C 412-414 (2004) 1484-1490

24) Y. Hatsukade, A. Kosugi, K. Mori and S. Tanaka: "Eddy-currentbased nondestructive inspection system using superconducting quantum interference devices for thin copper tubes”, Jpn. J. Appl. Phys. 43 (2004) L1488-L1491

25) Y. Hatsukade, A. Kosugi, K. Mori and S. Tanaka: "Nondestructive inspection using an HTS SQUID for copper heat-exchanger tubes", TEION KOGAKU 40 (2005) 319-326 (in Japanese) 廿日出好, 小杉明史, 森 憲亮, 田中三郎：「高温超伝導 SQUID を用いた銅製伝熱管表面の微細欠陥の非破壊検査」, 低温工学 40 (2005) 319-326

26) Y. Hatsukade, A. Kosugi, K. Mori and S. Tanaka: "Detection of micro flaws on thin copper tubes using SQUID-NDI system based on eddy current technique", Physica C 426-431 (2005) 1585-1590

27) Y. Hatsukade, S. Okuno, K. Mori and S. Tanaka: "Eddy-currentbased squid-nde for detection of surface flaws on copper tubes", IEEE Trans. Appl. Supercond. 17 (2007) 780-783

28) Y. Hatsukade, K. Yotsugi, Y. Sakaguchi and S. Tanaka, "Nondestructive inspection using HTS-SQUID on aluminum liner covered by CFRP”, Physica C 463-464 (2007) 1043-1047

29) Y. Hatsukade, A. Miyazaki, H. Matsuura, T. Maeda, Y. Fuke and S. Tanaka: "Inspection of wire breakage in aluminum transmission lines using an HTS SQUID”, TEION KOGAKU 44 (2009) 61-67 (in Japanese)

廿日出好, 宮崎敦司, 松浦英樹, 前田龍己, 福家靖司, 田中 三郎：「高温超伝導 SQUID を用いたアルミ撚り線の素線断線 の検出」, 低温工学 44 (2009) 61-67

30) S. Kanai, Y. Hatsukade, K. Hayashi, K. Mori and S. Tanaka: "Eddy-current-based SQUID-NDE system for copper tubes with laser displacement sensor", IEEE Trans. Appl. Supercond. 19 (2009) 786-790
31) Y. Hatsukade, T. Inaba, Y. Maruno and S. Tanaka: "Mobile cryocooler-based SQUID NDE system utilizing active magnetic shielding", IEEE Trans. Appl. Supercond.15 (2005) 723-728

32) Y. Hatsukade, K. Yotsugi and S. Tanaka: "Mobile HTS-SQUID NDE system with robot arm and active shielding using fluxgate", Physica C 468 (2008) 1932-1935

33) Y. Hatsukade, K. Yotsugi, S. Kanai, K. Hayashi and S. Tanaka: "Robot-arm-based mobile nondestructive inspection system using a cryocooler-based HTS-SQUID gradiometer", TEION KOGAKU 44 (2009) 54-60 (in Japanese)

廿日出好, 代継浩平, 金井翔, 林 啓太, 田中三郎：「冷 凍冷却 HTS-SQUID グラジオメータを用いたロボットアーム 式モバイル非破壊検査装置の開発」, 低温工学 44 (2009) 5460

34) Y. Hatsukade, K. Yotsugi, S. Kanai, K. Hayashi, H. Wakana, Y. Tarutani, K. Tanabe and S. Tanaka: "Robot-based NDE system using 3D-Mobile HTS-SQUID”, IEEE Trans. Appl. Supercond. 19 (2009) 796-800

35) Y. Hatsukade, K. Hayashi, Y. Shinyama, S. Adachi, K. Tanabe and S. Tanaka: "Characteristics of an HTS-SQUID gradiometer with ramp-edge Josephson junctions and its application on robot-based 3D-mobile compact SQUID NDE system”, Physica C 471 (2011) 1228-1233

36) Y. Hatsukade, N. Kasai, H. Takashima, Y. Maruno and A. Ishiyama: "Development of a low-magnetic-noise nondestructive inspection system using a superconducting quantum interference device cooled by a coaxial pulse tube cryocooler", TEION KOGAKU 38 (2003) 686-692 (in Japanese)

廿日出好, 葛西直子, 高島 浩, 丸野善生, 石山敦士：「同 軸型パルスチューブ冷凍機を用いた低磁気ノイズ SQUID 非 破壊検査システムの開発」, 低温工学 38 (2003) 686-692

37) http://www.samtech.co.jp/english/products/hpc.html

38) S. Adachi, K. Hata, H. Suagano, H. Wakana, T. Hato, Y. Tarutani and K. Tanabe: "Preparation of multilyaer films for integrated high- $T_{\mathrm{c}}$ SQUIDs with ramp-edge Josephson junctions", Physica C 468 (2008) 1936-1941

39) Y. Hatsukade, Y. Kobayashi, R. Kurosawa, S. Tanaka, "Suppression of change of critical current of HTS dc-SQUID in magnetic field", Abstract of CSJ Conference 84 (2011) 123

廿日出好, 小林義幸, 黒澤龍一, 田中三郎：「磁場に対する HTS dc-SQUID の臨界電流変化の抑制に関する研究」, 第 84 回 2011 年度春季低温工学 ·超電導学会講演概要集 (2011) 123

40) Y. Hatsukade, K. Hayashi, M. Takemoto and S. Tanaka: "Determination of the robustness of an HTS SQUID magnetometer covered with a superconducting film shield in an ac field", Supercond. Sci. Technol. 22 (2009) 114010.

廿日出好昭和 51 年 2 月 26 日生。平成 15 年早稲田大 学大学院理工学研究科電気工学専攻博士課程修了。同年 4 月より 豊橋技術科学大学に勤務, 現在, 環境・生命工学系准教授として SQUID 応用研究に従事。低温工学・超電導学会, 応用物理学会 会員, 日本生体磁気学会会員。工学博士。 